\title{
Re-contextualising Catholic School Religious Education: Educating Young People Spiritually, Morally and Religiously for the $21^{\text {st }}$ Century
}

\begin{abstract}
Philip Phenix's (1964) book Realms of meaning: A philosophy of the curriculum for general education started the ever growing movement concerned with how school education might help young people in their search for meaning, purpose and values in times of rapid cultural change. Today, in globalised, digital, secularised culture, the importance and urgency of this role have never been greater. Religious Education, with core curriculum status in Catholic schools, has both credentials and precedents for studying directly the contemporary human quest for meaning to help resource the spirituality of young people, no matter what their religious disposition. But a 'course correction' is needed for the discourse of Catholic Religious Education which has 'drifted' almost so exclusively into ecclesiastical terminology that its educational credibility as a valuable spiritual/ moral school subject has been eroded, creating an ever widening discontinuity with the realities of the classroom and young people's spirituality. A more outward-looking and less Catholic-centric emphasis would help, without neglecting commitment to the faith tradition. While concerned with the Australian Catholic sector, the article may well have relevance to other countries and contexts.
\end{abstract}

\section{Keywords}

religious education, spirituality, Catholic schools, ecclesiastical drift. 


\section{Introduction: The role of a critical, evaluative religious education in resourcing young people's spirituality}

While the issue remains real, it has almost become something of a cliché to point out that we live in times of unprecedented change that make it difficult for young people to find meaning and purpose in life, and to propose that school education might be able to make some contribution to help them in this quest. People have been saying this for the past 50 years; ${ }^{1}$ and during this whole period, what they said was always true. Part of the problem today is that new, challenging issues are continually emerging at a faster rate than ever. From climate change to terrorism, globalisation to the coronavirus pandemic, trade wars to mistrust of politicians, refugee migration to new levels of populist nationalism, ${ }^{2}$ trending memes to online trolls, ${ }^{3}$ the list goes on, perhaps often overridden by individuals' anxiety about the performance of their precarious, projected identity on social media.

In 1967, this is what prominent Australian biologist and author Charles Birch thought about the question: "The problems are not out there for us to solve. But to solve us. "In his view, the most realistic and helpful human response is in the activity of trying to comprehend problems and in trying to find solutions - even if apparent success and progress always remain elusive. About the same time, Philip Phenix's ${ }^{4}$ book Realms of meaning: A philosophy of the curriculum for general education signalled the start of an ever growing movement concerned with how school education might help young people in their search for meaning, purpose and values in times of rapid cultural change. Today, in globalised, digital, secularised culture, the importance and urgency of this role have never been greater, especially where the traditional religious sources of meaning are no longer prominent or plausible reference points. Rather, many secularised,

${ }^{1}$ Cf. V. Frankl, Man's search for meaning, London 1964: Hodder \& Stoughton; L.C. Birch, Confronting the future: Australia and the world: The next 100 years, Melbourne 1975: Penguin.

2 Cf. F. Zakaria, GPS. Global Public Square. Program for discussion of contemporary social and political issues on CNN, 2019. See https://www.cnn.com/shows/fareed-zakaria-gps

https:/globalpublicsquare.blogs.cnn.com/category/gps-episodes/

https://globalpublicsquare.blogs.cnn.com/.

${ }^{3}$ Cf. G. Gorman, Troll hunting: Inside the world of online hate and its human fallout, Melbourne 2019: Hardie Grant.

${ }^{4}$ Cf. P. Phenix, Realms of meaning: A philosophy of the curriculum for general education, New York 1964: McGraw Hill. 
individualistic, young people in Westernised countries appear preoccupied with a consumerist lifestyle- while at the same time there are unprecedented high levels of anxiety, depression and mental health issues. In the same vein, US educators/authors Postman and Weingartner ${ }^{5}$ considered that there were no institutions or processes - including education and schooling - that could reliably solve the problems; but education was at least a good starting point because it could skill young people in critical thinking and research, resourcing their capacity to think about the issues and to make better informed decisions.

Australian philosopher of education Brian Hill ${ }^{6}$ summed up the potential contribution of education this way.

Regarding the school:

"the mission of education is to resource the choosing self"

Regarding religious education in any school type:

"The teaching of religion in school has certain limited but crucial educational purposes:

- To help students appreciate the importance of the spiritual quest; of working out where they are going as human beings.

- To help them to interrogate their own cultural conditioning and reach a position of being able to develop an adequate personal framework of meaning and value."

(along with other purposes)

Hill took for granted that the sense of freedom and individuality permeating Westernised cultures would ensure that young people will eventually construct their own meaning, values and beliefs - even if for some (or perhaps many?) this will not be a conscious, reflective process but more a popular, cultural socialisation. Nothing could stop the 'choosing'; but their choosing could be better educated. Hence, knowledge of contemporary issues and critical thinking would be important for informing life decisions, as well as knowledge of what one's own and other religious traditions were saying about meaning in life. The religion classroom should be the very place where one might expect that students could learn how to appraise the shaping influence of culture.

${ }^{5}$ Cf. N. Postman \& C. Weingartner, Teaching as a subversive activity, Harmondsworth 1969: Penguin.

${ }^{6}$ Cf. B.V. Hill, Exploring religion in school: A national priority, Adelaide 2004: Openbook; B.V. Hill, Values in free fall: Religious education and values in public schools, "Journal of Religious Education" (2006) 54 (2), p. 55. 
Religious Education, with core curriculum status in Catholic schools, has both the history, credentials and precedents for studying directly the contemporary human quest for meaning to help resource the spirituality of young people, whether they are religious of not. This meant broadening its scope beyond Catholicism to include study of other religions and of the ways in which culture influences spirituality.

In contemporary teaching in a number of curriculum areas, it is evident that this critical interpretation and evaluation of culture is occurring to some extentfor example in English, Science, History, Geography and Social Studies, to name some subjects. It would be incongruous and disappointing if this strategy was not a prominent part of religious education - the one subject you might expect to be especially interested in the spiritual/moral dimension to life.

As well as providing students with a study of their own religious tradition, religious education should help them become knowledgeable of the ways in which various other religious traditions are influential in pluralistic society - how they propose to their followers what it means to be human. ${ }^{7}$ Also, there needs to be a direct investigation of contemporary spiritual, moral and social issues as referred to above. Rossiter ${ }^{8}$ and Crawford and Rossiter (2006) argued systematically that critical interpretation and evaluation, together with a research-oriented pedagogy, should become a core dimension of religious education.It suffices here to list most of the headings from their discussion.

- Traditions for a critical dimension to education (Phenix, Freire, Critical Theory and Critical Pedagogy, Postman, Etc.)

- Raymond Williams' ideas about cultural agency and avoiding being 'passive consumers' of culture

- Catholic tradition for a critical dimension to evangelisation and education

${ }^{7}$ Cf. M.H. Grimmitt, Religious education and human development: The Relationship between studying religions and personal social and moral education, Great Wakering 1987: McCrimmons; R. Jackson, Rethinking religious education and plurality: Issues in diversity and pedagogy, London 2004: Routledge Falmer; R. Jackson, Religious Education for Plural Societies, London 2018: Routledge.

${ }^{8}$ Cf. G. Rossiter, Life to the full: The changing landscape of contemporary spirituality. Implications for Catholic school religious education, Sydney 2018: Agora for Spiritual, Moral and Religious Education, pp. 95-104.

${ }^{9}$ Cf. M. Crawford \& G. Rossiter, Reasons for living: Education and young people's search for meaning, identity and spirituality. A Handbook, Melbourne 2006: Australian Council for Educational Research. 
- Critical evaluation as a type of contemporary gospel pedagogy

- Scope and limitations for a critical evaluative religious education in the classroom

- Proposed content and topics

- Acknowledging the negativity and lack of engagement in students' attitude to religion and religious education (the 'psychology of the learning environment')

- Scheme for a spiritual/moral dimension to the school curriculum

- Personalism, meaningfulness and relevance in religious education

Just one argument will be outlined briefly here, proposing why the above dimension is now so important for the future trajectory of Catholic religious education in the $21^{\text {st }}$ century.

The large majority of students in Australian Catholic schools have what has been described as by researchers as a as an individualistic, DIY, secular spirituality. ${ }^{10}$ Some generations back, most people were socialised into the religious spirituality of their family. And this was the taken-for-granted and relatively unquestioned system for referencing their meaning, purpose and values. These days, many, including those who identify as being religious, have a functioning spirituality (and 'religion') that is constructed in a 'do-it-yourself' fashion in an eclectic way. They are more focused on lifestyle than on spirituality itself. Their spirituality may not be developed consciously. Rather, it is evident in the values they adopt, their commitments, lifestyle and motivations. In this sense it is an implied spirituality, and it may draw little from their religious tradition. It is often a spirituality that has absorbed uncritically the compelling world view that underpins contemporary consumerist lifestyle, which is orchestrated by the potent imagery and iconography of media advertising and marketing.

Statistically, 30\% of the Australian Catholic school students are not Catholic; ${ }^{11}$ and about $5 \%$ of the Catholic students (less than $4 \%$ of total students) are, or will be, regular participants at Sunday Mass.

${ }^{10}$ Cf. F. Schweitzer, Religious individualization: New challenges to education for tolerance, "British Journal of Religious Education" (2007) 29 (1), pp. 89-100; M. Crawford \& G. Rossiter, Reasons for living: Education and young people's search for meaning, identity and spirituality. A Handbook, Melbourne 2006: Australian Council for Educational Research; P. Hughes, Putting Life Together, Melbourne 2007: CRA / Fairfield Press; P. Hughes, Educating for Purposeful Living in a Post-Traditional Age, Melbourne 2017: Christian Research Association.

${ }^{11}$ Cf. NCEC, NCEC 2012 Annual Report. Canberra 2012: National Catholic Education Commission (NCEC). 
Two conclusions:

- A religious education that concentrates almost exclusively on Catholicism will be perceived as largely irrelevant by the students.

- Contemporary secular spirituality - especially its consumerist dimension - needs to be evaluated in terms of its cultural origins, psychological influence and principal values; it is like the new global 'religion'. Such evaluation ought to be an important task for religious education.

Undertaking such an investigation of spirituality can make religious education more meaningful for young people, whether they are formally religious or not - precisely because it taps into the areas of their lives where spiritual and moral issues/values come into play. Religious education can resource their capacity to look critically at the ways that culture can have a shaping influence on people's imaginations of life, values and lifestyle. This approach tries to engage at the psychological points where young people's hopes and life expectations are generated - the same points that are the principal targets for commercial exploitation by the consumerist complex.

This might at first sight be regarded as just a psychological study and not 'proper' religious education because it seems to have little to do with Catholic theology. But one can argue that this is being true to the core purposes of religious education which tries to educate and thus enhance the basic human spirituality of young people no matter what their religious disposition.

This approach can help make students' experience of religious education more relevant. This is a different question from trying to make the church more relevant. These two questions should not be conflated. Only the church itself can address the latter question. It is a mistake to think that religious education should be primarily about trying to make the church look more attractive and inviting for young people.

I consider that this evaluative approach and its justifying argument are not just pertinent to current Catholic religious education. They are just as applicable to state-developed Religion Studies courses. Elsewhere, it was argued that these courses in Australia are still mainly replicas of the sorts of 'descriptive' world religions courses in the United Kingdom in the early 1970s. In brief, their content is 'too tame' for contemporary relevance. ${ }^{12}$

${ }^{12}$ Cf. G. Rossiter, Historical perspective on the development of Catholic Religious Education in Australia: Some implications for the future, "Journal of Religious Education" (1999), 47 (1), pp. 5-18; M. Crawford \& G. Rossiter, Reasons for living: Education and young people's search 


\section{The rise of 'ecclesiastical drift' in Australian Catholic school religious education}

The above discussion proposes a dimension to religious education that is considered to be vital for young people in Catholic schools today. This is where religious education needs to be. But where is current Catholic religious education positioned in relation to it? My interpretation is that it is on a different trajectory that can be described as 'ecclesiastical drift'. And if this trajectory is to be evaluated, there is a need to understand how and why this track has been followed, and how it has affected the discourse of Australian Catholic religious education, and in turn, student perceptions and experience.

Three important points need to be made at the outset. Firstly: this critique of trends in talk about religious education in no way compromises the Catholic school's hope to promote personal Christian faith in its pupils. As Hill pointed out: "It is the hope of the Christian school that students will be brought to the brink of seriously considering the claims of Christ on their lives by accurate representation and critique of Christianity's evidence and truth-claims, coupled with an educationally adequate representation and critique of other truth claims and lifestyles which compete for attention in their society."13

Secondly: the focus here is on formal classroom religious education. It is not concerned with the prayer / liturgical life of the school or with the important place for extra-curricular, voluntary commitment groups. As Hill noted: "they provide forums which invite students to encounter models and persuaders who are enthusiastic to talk about the faith and to field sceptical questions about it, leaving the students free to choose what they will make of it."14

Thirdly: the arguments here are based on the fundamental presumption that the formal religion curriculum is arguably the most distinctively Catholic element in Catholic schools - and this has been the case since their historical origins.

Through different metaphors and perspectives, ecclesiastical terms can nuance the understanding of religious education from the church's point of view. But there is also a downside - too many normative ecclesiastical constructs

for meaning, identity and spirituality. A Handbook, Melbourne 2006: Australian Council for Educational Research.

${ }^{13}$ B.V. Hill, Personal communication, 2020.

${ }^{14}$ B.V. Hill, Personal communication, 2020. 
can constrain thinking and can stifle freedom and creativity, as well as create confusion about fundamental purposes.

Ecclesiastical drift has occurred in religious education where the discourse about its purposes and practices has gradually come to be dominated almost exclusively by constructs like faith development, faith formation, Catholic identity, new evangelisation and Catholic mission. Excessive use of this language, at the expense of the word education, turns the focus 'inwards' towards Catholicism - at the very time when more of an 'outwards' focus on the shaping influence of culture is needed. The purpose of getting young people to engage with the Catholic Church and become regular mass attendees tends to resonate with this emphasis, even if it is not made explicit. The ecclesiastical language dominance eclipses the educational dimension to religious education and what suffers is thinking about what it means to educate today's young people spiritually and religiously.

Four examples of the rise of ecclesiastical drift will be given and then its historical emergence will be traced and evaluated:

1. From the Australian Catholic bishops.

My concern has not been with [religious education] curriculum issues, but more with faith formation programs, seeking to know "what works".

In a letter from a bishop who had served as chair of the Bishops' Committee for Catholic Education.

The only purpose of Catholic schools is to fulfil the Catholic Church's mission. They should increase young people's engagement with the church and their attendance at Sunday mass.

Key ideas from the homily of an Australian Catholic bishop

2. Changes in the names of Diocesan Catholic School Religious Education Departments and for the role of school Religious Education coordinators, where the words 'education' and 'religious education' were gradually disappearing. 
Table 1.

\begin{tabular}{|l|l|}
\hline $\begin{array}{l}\text { Changed names for Diocesan Religious } \\
\text { Education Departments (Some exam- } \\
\text { ples) }\end{array}$ & $\begin{array}{l}\text { New names for Catholic school Reli- } \\
\text { gious Education Coordinators (Some } \\
\text { examples) }\end{array}$ \\
\hline Evangelisation and Catholic formation & $\begin{array}{l}\text { Head of Catholic Identity and Action } \\
\text { Assistant Principal Identity. }\end{array}$ \\
Catholic Mission \& Identity & Assistant Principal Religious Education, Identity and \\
Enhancing Catholic School Identity & Mission \\
Department of Mission & Director of Identity and Student Formation \\
Catholic Life, Education and Mission & Director of Mission and Catholic Identity \\
Identity, Mission and Religious Education & Dean of Mission. \\
Faith Education and Formation & Director or Evangelisation \\
Learning, Teaching and Catholic Identity & Director of Religious Education and Evangelisation \\
Faith and Life & Director of Faith and Outreach \\
Catholic life and Mission & Director of Faith and Mission \\
Faith Education and Learning & Faith Development Coordinator \\
Mission and Evangelisation & Ministry coordinator \\
Identity and Mission & Director of spiritual activities \\
Catholic Identity and Evangelisation & \\
Identity and Liberating Education & \\
\hline
\end{tabular}

3. From the literature tuned in to ecclesiastical drift.

Learn how to put the Catholic back into Catholic schools.

From the website advertising a new Australian book on Catholic mission in education.

An Educator's Guide to Mission in Practice: Discipleship in Action in Catholic Schools

Title of a new book on Catholic schooling (2019)

4. From a new Catholic school Religious Education program for years 11-12.

In the draft syllabus of a NSW Catholic schools program Studies in Catholic Thought, the word 'Catholic' is used 538 times, while the word 'religion' appears 9 times.

\subsection{Historical perspective}

Until the end of what might be called the catechism era in Australian Catholic school religious education in the early 1960s, the activity was commonly called Christian Doctrine. This was an accurate description of what happened in the classroom which was all about knowledge of Catholic teaching, together with an element of exhortation to live as good Catholics. 
Coinciding with the Second Vatican Council, and influenced perhaps even more by sociocultural and educational change, in the 1960 s and 1970s, the catechism era was replaced by a period of experimentation aimed primarily at making religious education more personal and relevant for young people. ${ }^{15} \mathrm{~A}$ variety of names for the subject appeared such as Christian living, Religious Knowledge, Community Development Studies etc.; but soon the term Religious Education became the established norm. ${ }^{16}$ This implied that theology or Christian doctrine were inappropriate terms because the emphasis was on 'educating' students religiously. The differences in meaning between the terms faith, beliefs, theology, and religious education were well articulated at the time by US theologian Richard McBrien. ${ }^{17}$

While the importance of a sound education in Catholicism was never in question, few if any religion teachers at the time thought about their role exclusively in terms of getting young people to go to Mass on Sundays. They never saw religious education as just an ecclesiastical activity. Trying to address the personal development needs of youth was prominent in their understanding of religious education. This was evident in the interest shown in US religious researcher Merton Strommen's 1974 book The five cries of youth. For religion teachers at this time, there appeared to be a constructive, creative tension between ecclesiastical concerns and concerns for the personal development of young people.

\subsection{The emergence of diocesan Catholic Education Offices and religious education authorities}

During this period, practically all Catholic school religion teachers were members of religious orders. While there were some diocesan religion syllabuses, schools and religion teachers had great freedom and independence, and this

${ }^{15}$ Cf. G. Rossiter, Religious Education in Australian Schools, Canberra 1981: Curriculum Development Centre; G. Rossiter, Historical perspective on the development of Catholic Religious Education in Australia: Some implications for the future, "Journal of Religious Education" (1999), 47 (1), pp. 5-18; T. Lovat, What is this thing called Religious Education? (3rd Edition), Terrigal 2009: David Barlow; M. Ryan, A common search: The history and forms of religious education in Catholic schools (Revised Edition), Brisbane 2013: Lumino Press.

${ }^{16}$ Cf. T.A. O'Donoghue \& D. Byrne, Historical Inquiry into the Construction of Religion as a School Subject for Catholic Schools in Australia, "eJournal of Catholic Education in Australasia" (2014), Vol. 1: Iss. 1, Article 2. Available at: http://researchonline.nd.edu.au/ecea/vol1/iss1/2.

${ }^{17}$ Cf. R.P. McBrien, Catholicism. Melbourne 1976: Dove Communications. 
supported extensive experimentation in times when SBCD (School based curriculum development) was in vogue. Only gradually, after the securing of state funding for the maintenance and growth of independent school systems, came the emergence of diocesan Catholic Education Offices and religious education consultants, together with the introduction of mandatory, centralised syllabuses and guidelines. This effectively ended the widespread experimentation and coincided with the rise and general acceptance of a 'subject-oriented' understanding of religious education as a core element in the Catholic school curriculum. ${ }^{18}$

From this time, the discourse of Catholic school religious education became more coherent and unified under the leadership of diocesan religious education authorities/consultants/advisers. How these personnel formulated their understanding of religious education and how this was propagated in the dioceses through documents and professional development programs determined in large measure the key words and concepts that were to be used for articulating the purposes of religious education. Their view of religious education would have been influenced by their undergraduate and postgraduate studies. Employed directly by diocesan offices, they would be likely to be more deferential to the religious education views of bishops than the average religion teachers in schools; and perhaps more attentive to ecclesiastical expectations and language. As might be expected, the content for school religious education specified by the bishops was primarily theological and in most cases was similar to the traditional theology content outlines in Catholic seminaries.

It was not that there was a conscious conspiracy to make ecclesiastical concerns the exclusive focus of religious education. But diocesan personnel, along with religious educators at tertiary level, while setting out to develop and enhance religious education, drifted incrementally into ways of thinking and talking about religious education that had unintended negative consequences. There ended up being such a strong and relatively unquestioned ecclesiastical emphasis in the language of religious education that its educational dimension was eroded. The discourse seemed more appropriate for a seminary than for a semi-state Catholic school. Religious education tended to become a subset of Catholic identity or evangelisation rather than the reverse. Ambiguity in both the theory and practice of religious education followed.

${ }^{18}$ Cf. G. Rossiter, Life to the full: The changing landscape of contemporary spirituality. Implications for Catholic school religious education, Sydney 2018: Agora for Spiritual, Moral and Religious Education, p. 86. 


\subsection{The influence of church documents}

which had a bearing on religious education

Identifiably influential on the Australian discourse of religious education were the Catholic Church documents (mainly from Rome, as well as national and diocesan) that had a bearing on religious education, even if their focus was mainly on pastoral ministry. Those from the Roman Congregation for Catholic Education were more focused on Catholic schools and religious education than the other documents from Popes and the Congregation for the Clergy.

Rossiter $^{19}$ analysed the historical pattern in key word usage in 6 principal church documents. It was surprising to note that the first of these, the Vatican II 1966 document Gravissimum Educationis (Declaration on Christian Education), focused mainly on the word education. The surprise was that this word was not ecclesiastical - it was not 'owned' by the bishops or church as were words like catechesis and evangelisation; this emphasis was expansive, outwards-looking and ecumenical in scope. It was naturally open to dialogue with other Christian denominations where 'Christian education' was prominent. It also articulated with the wider, international discourse of education, showing how education within a particular religious tradition and educating individuals' faith could make a valuable contribution to their spiritual and moral development, as well as to civic education. Perhaps not all of the bishops at that time would have read these expansive implications into the document they approved; their attention was likely to be preoccupied with the other major Vatican II documents. But nevertheless, it was published and it was quickly regarded as a pivotal source of inspiration for religious education in the future. This was evident in the 1970 Australian Bishops document The Renewal of the Education of Faith (translated from the Italian bishops' document published earlier) which elaborated on what it meant to educate in the faith tradition and to educate personal faith.

After Vatican II, in successive Roman documents, attention to the word education quickly declined while faith, catechesis and evangelisation became much more prominent. Faith became the principal focal point, rather than religious knowledge. And practically all of the church-favoured words that were to follow would be 'faith derivatives'. Faith replaced doctrine which had been the key word for a long time. Inevitably, this usage (especially catechesis) inhibited ecumenical

${ }^{19}$ Cf. G. Rossiter, Life to the full: The changing landscape of contemporary spirituality. Implications for Catholic school religious education, Sydney 2018: Agora for Spiritual, Moral and Religious Education, pp. 88-93. 
links with those outside the Catholic Church who were engaged in education and Christian education. From then on, the discussion of religious education from a normative Roman Catholic perspective tended to become 'in-house' and not readily open to the wider educational discourse because it was more or less locked in to a set of ecclesiastical constructs that had little currency outside the Catholic Church. This also meant that the religious education endeavour was then likely to be understood and talked about more as if it were an ecclesiastical activity. The more ecclesiastical, and correspondingly the less educational, it was perceived to be, religious education could be expected to have an increasingly ambiguous place in the Catholic school curriculum - even if this were to occur incrementally and slowly. If it was not regarded primarily as education, in all likelihood this would eventually have negative consequences for the perceptions of teachers, students and parents.

There would be a counter-balance. Diocesan Catholic Education authorities endeavoured to establish the educational credentials of religious education. They developed curricula that corresponded with government education standards and protocols for curriculum development with attention to the specification of outcomes, performance indicators and assessment. The academic status of religious education was also reinforced by the Congregation for Catholic Education's 1988 document The religious dimension of education in a Catholic school. But the ecclesiastical language problem would remain and intensify. Cautioning about this problem should not be interpreted as saying that ecclesiastical interests in Catholic school religious education are being rejected. What is needed is a constructive, balanced relationship between ecclesiastical and educational concerns. I consider that at present there is an imbalance that needs to be redressed.

In 2007, the Catholic bishops of NSW and ACT published the document Catholic schools at a crossroads which was the first Australian episcopal document to use the words 'faith formation' and 'Catholic identity' which have now become very prominent in the discourse of Catholic religious education. This document talked about religious education as if it were primarily an ecclesiastical process. It considered that despite the high level of resources invested in Catholic schools, they were not successful in inclining young Catholics to become regular church goers. Because of low church participation rates amongst Australian Catholic youth, it was felt that there must be a crisis of Catholic identity in Catholic schools. New evangelisation and strengthening Catholic identity were proposed as principal strategies for 'reigniting' 
young people's spirituality and improving their engagement with the Church. Increased Sunday mass attendance was listed as a performance indicator for Catholic schools.

The interpretations in this document can be contested. There appears to be no evidence of any recent crisis of identity in Australian Catholic schools. There is no statistical evidence of any causal links between Catholic schooling/religious education and the ultimate mass attendance rates of Catholic school graduates. No matter what the quality of school religious education, it cannot make the church more attractive to young people - only the church itself can do this. While there is evidence of a widespread crisis in the Catholic Church, this cannot be said of Catholic schools in Australia, which are thriving. Observers can readily note that there is a 'booming' Catholic school system in a declining church. Making the church more relevant is of great concern for Catholics, but it has a different and extensive agenda to be addressed, and school religious education has little to do with that.

\subsection{Increased attention given to ecclesiastical constructs}

Faith development: The construct 'faith development' made its first appearance in the discourse of Australian Catholic religious education after the publication of John Westerhoff's Will our Children have Faith ${ }^{20}$ and James Fowler's Stages of faith: The psychology of human development and the quest for meaning. ${ }^{21}$ Subsequently, it became an ecclesiastical 'buzz' word and was ubiquitous in the discourse; in some instances it displaced the term religious education. A detailed discussion of the issues its usage created appears in chapters 18 and 19 of Reasons for living $g^{22}$ and chapter 5 of Missionaries to a teenage culture. ${ }^{23}$

Faith formation: Now it is the term 'faith formation' that is being used increasingly as a substitute for religious education. The episcopal preference for

${ }^{20}$ J.H. Westerhoff, Will our Children have Faith?, Melbourne 1976: Dove Communications.

${ }^{21}$ J. Fowler, Stages of faith: The psychology of human development and the quest for meaning, Melbourne 1981: Dove Communications.

${ }^{22}$ M. Crawford \& G. Rossiter, Reasons for living: Education and young people's search for meaning, identity and spirituality. A Handbook, Melbourne 2006: Australian Council for Educational Research.

${ }^{23}$ M. Crawford \& G. Rossiter, Missionaries to a teenage culture: Religious education in a time of rapid change, Sydney 1988: Christian Brothers Province Resource Group. 
faith formation over religious education was noted in the quotation at the start of this section. It appeared as far back as 1987 , exemplified in the comments of a priest Diocesan Director of Catholic schools: "What we need is faith formation and not religious education". Since that time, I found that those who used the term rarely if ever defined what they meant by faith formation and how it might evidently be different from religious education. It appeared to be used with the connotation that somehow faith formation was more important and influential than religious education - as if the intention to form faith made the activity more effective in changing both the quality of the individual's personal relationship with God and their level of engagement with the church. Education was apparently considered inferior to, and less powerful than, formation. No indication was given about how an observer could look at activities and clearly see why one was faith formation and others were 'merely' religious education. Also apparent in the connotation was the presumption that it enhanced recruitment to regular mass attendance; this seemed to be the criterion of faith formation that 'works'. This language trend devalues religious education and creates ambiguity about its purposes in the school curriculum; and this in turn can weaken its status as a challenging, academic subject.

The Australian National Catholic Education Commission's document on faith formation for Catholic educators defined it as follows: - "Faith formation... is an intentional ongoing and reflective process that focuses on the growth of individuals and communities from their lived experiences, in spiritual awareness, theological understanding, vocational motivation and capabilities for mission and service in the church and the world." ${ }^{24}$

Some could equally use many of these same words to characterise religious education. This suggests an ambiguity that in my observation always seems to be present where people use the term faith formation.

Australian Catholic use of the term faith formation has etymological roots in the words 'houses of formation' in first half twentieth century religious order and seminary practice. Formation was like a 'religious Marine boot camp. The emphases were: - conformity, 'marching in formation', uniformity, obedience, repression of individuality, suspicion of personal relationships, being moulded and changed personally according to a desired model. Faith formation tends to become something of an oxymoron when this connotation is compared with

${ }^{24}$ NCEC, A Framework for Formation for Mission in Catholic Education, Sydney 2017: National Catholic Education Commission (NCEC), p. 9. 
a comprehensive view of Christian faith as a committed personal relationship with God, and as a gift from God freely accepted. ${ }^{25}$ There are significant differences between the connotations of the root words for 'educate/education' and 'form/formation' in English, French, German, Italian and Japanese (for example). These differences suggest to me that religious educators would do well to avoid putting the words 'faith' and 'formation' together.

Education today tends to connote being informed, critical thinking and personal autonomy. It may be that fear of such potential could foster a negative view of religious education and a more positive valuation of faith formation because the latter seemed to better serve ecclesiastical purposes.

Faith formation tends to be used more with reference to voluntary religious ministry programs than with reference to formal religious education. But its increasing prominence in schools is now eclipsing religious education.

A division between 'educational' and 'faith formation/faith development' aspects of the school's overall religious education has been used to make helpful distinctions; but it used the wrong language to do so. It made long term outcomes, or more accurately 'hopes', take the place of the main process word. It gave an impression that the educational engagement with religion in the classroom did not contribute to the development of the individual's personal faith - and this is not the case. The classroom study of religion can make a vital contribution to the understanding and theological dimensions of personal faith. This would be the one aspect of the overall development of an individual's faith that is most in tune with what schools do best - educate.

Catholic identity: The frequency of writings that include key words in the Journal of Religious Education (Australian) since 1995 is some measure of their currency in Australian Catholic religious education. The words 'Catholic identity' first appeared in the journal in 1997 (with 36 other articles registering the same key word between 1997 and 2013). This first article considered that an interest in the term 'Catholicity' of Catholic schools preceded, and was the synonym for, Catholic identity (20 articles in the same period used the word Catholicity).It argued that the catalyst for the emerging interest in Catholicity/Catholic identity were "concerns ... that [Catholic schools] are not distinctively Catholic, and that they are not as effective as they might be in communicating a sense of Catholic

${ }^{25}$ Cf. G. Rossiter, Life to the full: The changing landscape of contemporary spirituality. Implications for Catholic school religious education, Sydney 2018: Agora for Spiritual, Moral and Religious Education, pp. 9-15. 
identity. "It acknowledged the importance of the Catholic school and religious education in resourcing the personal identity development of young people. It went on to propose that.

The nature and development of religious identity are very complex. If considerations of the issue are to be discerning and are to lead to useful implications, then simplistic solutions need to be avoided. The real possibilities and limitations of a school for helping foster a sense of religious identity have to be understood.

It is important to recognise that the term 'Catholic identity' is ambivalent and difficult to define - as with any other identity: Anglican, Muslim, etc. While a general picture of Catholic identity can be established by what is stated in orthodox beliefs and religious practice, individuals vary in the way they draw on formal beliefs and practices for their self-expression and self-understanding.

Firstly, the Catholic school needs to have enough of the externals and religious practices of the Church to give some physical colouring to the identity building resources that it makes available to its students. They need to have first-hand experience of Catholic liturgy, prayer and spirituality. And they need adult Catholic role models who share this religious practice with them and who teach them about it in the classroom.

Secondly, the curriculum (and the religion curriculum in particular) should give pupils the opportunity for becoming familiar with the historical traditions of belief and practice of the church. The concept 'access' is crucial here because identity cannot be forced on individuals.

Thirdly, for the older pupils, there should be an opportunity to study the process of development of religious identity. This means becoming more informed about, and learning to think critically about, the problematic nature of religious identity in today's multi-faith, multicultural, secular society. It gives students the chance to reflect on the way in which personal, family and cultural forces have a shaping influence on their own spirituality, morality and self-understanding. ${ }^{26}$

What was said then appears to be just as relevant to current discussions of Catholic identity as it was in 1997.

The article judged that the initial driving force behind the concerns about the Catholic identity of schools was from Catholics who were anxious about secularisation and the decline in church attendance; and they unrealistically blamed

${ }^{26}$ Cf. G. Rossiter, The 'Catholicity' of Catholic schools and the development of students' religious identity, "Word in Life" (1997), 45 (2), p. 20. 
the Catholic school and religious education for the problem. This criticism mirrored the complaints about Catholic schools/religious education made by the group Catholics Concerned for the Faith two decades before in the mid-1970s. ${ }^{27}$ These sorts of concerns have long been registered by a minority of Catholics. For example, in 2015, the Catholic journal $A D 2000$ reported the following letter from concerned Catholics.

"We firmly believe that the Church has a major problem with its delivery of religious education in her school system and think that urgent action is required to improve her performance."

"A mere $20 \%$ of students in the Catholic school system attend Mass on Sunday during their schooling, but $72 \%$ of them stop practising their faith by the time they are 29 years of age."

"...there is something drastically wrong with the curriculum and the way it is being taught."

"...While the school factor appears to be the major factor causing students and ex-students to stop practising their faith, other factors also contribute such as the family situation, mass media especially TV and social media."

“...The crisis in Catholic education suggests that the curriculum is lacking. Children need to be made familiar with the Catholic Catechism, the Bible references and the importance of going to Mass every Sunday at the very least."

The above discussion suggests that the first impulse in the emergence of the term Catholic identity as a key word in the discourse of Catholic religious education came from anxiety about the future of the church which was in decline. It is not unlikely that this same impulse motivates concerns about the Catholic identity of schools today to varying degrees. For example, the advertising comment quoted earlier "Learn how to put the Catholic back into Catholic schools" is misleading. It appears to be making an emotional appeal. What 'Catholic' elements have gone? How and why did they go missing? And how might they be 're-injected' into Catholic schools? Unfortunately, the term Catholic identity is readily perceived as an ambiguous slogan that does not promote realistic expectations of religious education.

The second impulse driving the current interest in the Catholic identity of schools came from a very different direction. It originated in European religious education and theology (mid 1990s and 2000s) which had taken

${ }^{27}$ Cf. G. Rossiter, The Place of Knowledge in Religious Education: The Debate over Doctrine in Religious Education, "Our Apostolate" (1977) 25 (4), pp. 214-223. 
up a strong interest in personal identity development. Three examples illustrate this: - C. Hermans ${ }^{28}{ }^{28}$ concerned with how religious education might resource personal identity development; Pajer ${ }^{29}$ reviewed European thinking about how the changing sense of cultural identities in Europe were influencing religious education; In 2001, a group of international scholars in theology, religious education and psychology/sociology met at the Catholic University of Nijmegen for a conference on identity development and education.

The Enhancing Catholic Schools Identity Project (ECSIP): It was from this background that the work of Catholic University of Leuven theologians, Lieven Boeve and Didier Pollefeyt, came to have the most potent of all influences on Australian interest in the Catholic identity of schools.

Beginning in 2006, the Enhancing Catholic School Identity Project is the largest and most ambitious empirical research and action activity in the history of the Catholic school sector. It aimed at renewing the culture and identity of Australian Catholic schools. ${ }^{30}$ It began for schools in the three Victorian Catholic dioceses and it has also been taken up in other states. At the heart of the project, and in my opinion, its driving force, has been Boeve's ${ }^{31}$ theology

${ }^{28}$ Cf. C. Sterkens, C.A.M. Hermans, J.A. Van der Ven, Formation of the Religious Polyphonic Self: Interreligious Learning in Religiously Affiliated Schools, in: P. Ploeger \& C. Sterkens (Eds.), Search for Meaning. Education into Realms of Meaning in a Plural Society, Kampen 1999: Kok, pp. 219-250.

${ }^{29}$ Cf. F. Pajer, School-based education and religious culture: A European approach to the problem of teaching religion in school. De La Salle Brothers International (2003) MEL Bulletin 6. Published in the "Journal of Religious Education" (2006), 54 (4), pp. 37-45.

${ }^{30}$ Cf. D. Pollefeyt \& J. Bouwens, Framing the identity of Catholic schools: Empirical methodology for quantitative research on the Catholic identity of an education institute, "International Studies in Catholic Education" (2010) 2 (2), pp. 193-211; D. Pollefeyt \& J. Bouwens, Identity in Dialogue: Assessing and enhancing Catholic school identity. Research methodology and research results in Catholic schools in Victoria, Australia, Melbourne 2012: Catholic Education Commission of Victoria and Katholieke Universiteit Leuven (Faculty of Theology and Religious Studies, Final Draft for Publication). Melbourne: Catholic Education Commission of Victoria and Katholieke Universiteit Leuven. Published in 2014 by Lit Verlag GambH \& Co, Zurich; P. Sharkey, Educator's Guide to Catholic Identity, Melbourne 2015: Vaughan Publishing; P. Sharkey, Better understanding of the context of religious education: The CEVC Leuven Research, in: R. Rymarz and A. Belmonte (Eds.), Religious Education in Australian Catholic Schools: Exploring the landscape, Melbourne 2017: Vaughan Publishing.

${ }^{31}$ Cf. L. Boeve, Interrupting Tradition: An Essay on Christian Faith in a Postmodern Context, Louvain 2003: Louvain Theological and Pastoral Monographs; L. Boeve, Religion after detraditionalization: Christian faith in a post-secular Europe, "Irish Theological Quarterly" 
of interruption and recontextualisation. He thought that cultural upheavals brought about discontinuities in the way religious traditions were handed on from generation to generation. But in the spirit of Pope John XXIII's exhortation to 'read the signs of the times', Boeve saw the interruptions as opportunities for Christianity, and theology in particular, to recontextualise and re-orient their endeavours to dialogue critically and constructively with culture to address the spiritual needs of the new situation. This is quite different from impulse 1 above which tended to come from fear (and even panic) about the impact of cultural change on the church. Boeve ${ }^{32}$ wrote "Every new context challenges the Christian tradition to recontextualise its presentation of meaning and purpose in a cogent and credible fashion."

Boeve was also interested in identifying what sort of institutional culture (or identity) would be most helpful for responding creatively to secularised society. Pollefeyt followed this through for Catholic schools with empirical measures of their spiritual/religious culture. The ultimate purpose was to foster a recontextualised Catholic spirituality, informing school culture and practice. In my view, Boeve's approach is continuous with the long tradition since Vatican II, trying to re-imagine how Catholicism might best respond to the modern world. His ideas on recontextualising are both important and challenging; but I think that linking and 'badging' them with the term Catholic identity has handicapped the recontextualising agenda, mainly because of the problematic nature of that term. When people hear the words Catholic identity, most do not readily associate this with the challenge of recontextualising Catholicism for the future - instead they may well think it is about 'Making the Catholic Church great again' - in short, a problematic restorationism.

Pope Francis' comments which are relevant both to recontextualisation and restorationism are pertinent here. "If the Christian is a restorationist, a legalist, if he wants everything clear and safe, then he will find nothing. Tradition and memory of the past must help us to have the courage to open up new areas

(2005) 70 (2), pp. 99-122; L. Boeve, God interrupts history: Theology in a time of upheaval, New York 2007: Continuum; L. Boeve, Communicating faith in contemporary Europe: Dealing with language problems in and outside the church, in: J. Sullivan (Ed.), Communicating faith, Washington 2011: Catholic University of America Press; L. Boeve, Theology at the Crossroads of University, Church and Society: Dialogue, Difference and Catholic Identity, London 2016: Bloomsbury.

32 Cf. L. Boeve, Interrupting Tradition: An Essay on Christian Faith in a Postmodern Context, Louvain 2003: Louvain Theological and Pastoral Monographs. 
to God....those who stubbornly try to recover a past that no longer exists - they have a static and inward-directed view of things. In this way, faith becomes an ideology among other ideologies. ${ }^{33}$

Catholic identity and religious education: It is important to distinguish the concerns of ECSIP with school culture from its potential impact on religious education. ${ }^{34}$ Here the interest is only in the latter - the success of the project in terms of its own purposes is not in question here. I think that the ECSIP has not had any negative effects on Catholic religious education directly. But there appear to be unintended negative consequences for religious education where the new preoccupation with Catholic identity is applied to religious education. Negativity is generated because echoes of impulse 1 (noted above) seem to come into play. Students/parents perceive Catholic identity as church-focused and not directly concerned with individuals or their education; it appears to be inwardlooking and about re-establishing the church, and not outward-looking about how culture affects people's spirituality. For the $30 \%$ of students who are not Catholic, and for non-Catholic teachers, the term is often felt to be exclusivist and repressive.

The preoccupation with Catholic identity in Catholic schools is also evident where a number of new leadership positions have emerged to replace those formerly related to religious education - as illustrated earlier in Table 1, which also showed how former Diocesan Office Religious Education Departments were re-badged with ecclesiastical titles. One might wonder about the negative implications in the change of names where the words religious education often disappeared - as well as being concerned about why these changes were made. This development would have to create some ambiguity about purposes and expectations for religious education, ${ }^{35}$ and would reinforce the impression that it was an ecclesiastical rather than an educational activity. Consider for

${ }^{33}$ Cf. Pope Francis I, The interview with Pope Francis I, "La Civiltà Cattolica”, August 2013 (English translation, "America”, September 30, 2013), pp. 8, 11.

${ }^{34}$ G. Rossiter, Life to the full: The changing landscape of contemporary spirituality. Implications for Catholic school religious education, Sydney 2018: Agora for Spiritual, Moral and Religious Education, pp. 117-120.

${ }^{35}$ Cf. M.T. Buchanan, The Transmission of Religion: Reconceptualising the Religious Education Leader, in: M.T. Buchanan \& A.-M. Gellel, (Eds.), Global Perspectives on Catholic Religious Education in Schools: Volume II: learning and leading in a pluralist world, Singapore 2019: Springer Nature, p. 140. 
example, where some religion teachers in a school thought about Catholic identity as a challenging invitation to recontextualise religious education for critical dialogue with culture (Impulse 2). ${ }^{36}$ They may have colleagues who were equally enthusiastic about Catholic identity, but had a different interpretation of what it means - a need to get back to what Catholicism was like at an earlier period when there were more mass-attending Catholics (Impulse 1); this was described by Boeve as a re-confessionalising agenda. But it will not really matter what the teachers think if most of the students feel that Catholic identity is largely irrelevant and meaningless for them.

Boeve's theology aims at recontextualising Catholicism and it has been used to promote recontextualised Catholic schools. Both tasks are very complex and difficult to achieve because they depend ultimately on changing people's attitudes and spirituality significantly in the direction of a 'post-critical belief' that 'interrupts and reconfigures the context' opening it 'anew towards the reality of God. ${ }^{37}$ There are Catholics who have been trying to so this since the Second Vatican Council. While their own lives have been transformed, how much recontextualising has affected bishops and clergy remains an open question. On the other hand, it is much easier and quite feasible to recontextualise the Catholic school religious education curriculum. The first steps simply need changing the syllabus content and methodology. However, the human factor remains critical and not much will happen until the Religious Education authorities are prepared to acknowledge and address both the problem of ecclesiastical drift in their discourse and the reality of secular spirituality in most families with children at Catholic schools.

The issues raised here are controversial. It would help to research the views of students, parents and teachers. But this would require courage and openness to ask the difficult questions.

${ }^{36}$ Cf. G. Rossiter, Life to the full: The changing landscape of contemporary spirituality. Implications for Catholic school religious education, Sydney 2018: Agora for Spiritual, Moral and Religious Education, p. 134.

${ }^{37}$ L. Boeve, God interrupts history: Theology in a time of upheaval, New York 2007: Continuum. 


\section{The effects of ecclesiastical drift on religious education in Catholic tertiary institutions}

Catholic tertiary institutions such as Catholic universities, and to a lesser extent, theological colleges, both in Australia and overseas, have long provided an academic superstructure for Catholic school religious education. This is more prominent in countries like Australia and Ireland where tertiary religious education is linked with substantial Catholic school systems and their need for the professional and academic development of religion teachers.

Religious education academics engaged in research, dialogue with the international scholarly literature, writing, and teaching at both undergraduate and postgraduate levels - as well as in various professional development activities. They were at the nexus between academia and practitioners. Here, religious education always had an identifiable, departmental structure, whether this was in faculties of education or theology. In situations where the Catholic school systems were not so prominent, the term Practical Theology was sometimes the preferred term in place of religious education. ${ }^{38}$ Ideally, these academics helped provide the school religious education endeavour with vital academic perspectives: - research, interdisciplinary, international, pedagogical and independence. This group, together with diocesan and any national religious education authorities, provided a type of functional, collective leadership. But as far as the discourse of school religious education was concerned, it was the diocesan leadership which defined the language and key constructs that would be used for elaborating its purposes and practices - making their influence pivotal in the discourse of Australian Catholic religious education.

Ecclesiastical drift has affected religious education in Catholic tertiary institutions, and in some instances, the influence has been even more dramatic than in the schools - mutually reinforcing its effects on the whole Catholic education enterprise. Here there is evidence not just of drift, but of direct action - an intention not to promote religious education, but to 'demote', restrict and control it.

One could anticipate that this might affect religious education in four ways.

1. The appearance of Catholic Identity and Mission as a principal construct and structure for articulating the distinctive Catholicity of a university, a role that was previously felt to be adequately spoken for by structures for theology, religious education, philosophy and campus ministry.

\footnotetext{
${ }^{38}$ Cf. J. Swinton \& H. Mowat, Practical theology and qualitative research, London 2016: SCM.
} 
2. Downgrading the status of research in the academic discipline of religious education, and minimising or extinguishing its research capacity.

3. Changing the emphasis in course work from education towards youth ministry and pastoral concerns. This could include new postgraduate units and programs in Evangelisation and/or Catholic Identity as alternatives to those in religious education. A tendency to regard religious education as a subset of campus ministry.

4. Dissolving a distinctive and identifiable institutional structure for religious education so that religious education academic staff were absorbed generically into either theology or education. If located within a faculty of theology, this may also have included the requirement that religious education staff be 'mandated' by the local bishop, as is usually the case for theologians. Previously in most circumstances, a mandatum was not required for religious education academics. They usually felt no need to have in their books a Catholic imprimatur and nihil obstat from a diocesan censor - unless it was a student religion textbook.

Any decline in religious education in Catholic tertiary institutions could be expected to have a flow on negative impact on Catholic schools. All education at tertiary level is expected to exhibit academic freedom which underpins the academy's capacity for innovation and critique. ${ }^{39}$ Hence any diminishing of tertiary religious education can in turn diminish freedom, sense of independence, novelty and creativity, and capacity for critical evaluation in Catholic school religious education.

While a close and harmonious relationship between Catholic theology and religious education is ideal, there has long been some tension between the two sometimes creative and sometimes destructive. Because of its ties to education and its interdisciplinary focus, religious education has had a sense of freedom and independence that Catholic theology has not enjoyed as far as ecclesiastical authorities were concerned. Religion teachers also have faced the sobering reality of many adolescents' disinterest in all things religious. They often say that theologians, priests and bishops would have a much better understanding of the whole enterprise of school religious education if they had to teach Year 9 and Year 12 students for a few years.

${ }^{39}$ Cf. T. Hesburgh, The challenge and promise of a Catholic university, South Bend 1994: University of Notre Dame Press; M.M. Morey \& J.J. Piderit, Catholic higher education: A culture in crisis, New York 2006: Oxford University Press. 
There has long been a lingering episcopal and clerical suspicion of religious educators at both school and tertiary level. There was not the same level of episcopal control over religion teachers as there appeared to be over Catholic theologians. This problem is also rooted in ecclesiastical expectations that religious education is primarily about imbuing young people with commitment to participation in the church, whereas most religion teachers have never seen this as an exclusive or realistic goal for religious education, and they have rarely thought about their task as just 'delivering' Catholic theology.

There is evidence of the negative influence of ecclesiastical drift in all of the above noted four modes in Australian Catholic tertiary religious education. While there is anecdotal evidence that it has also occurred in Catholic institutions overseas, the extent to which this may be the case is yet to be determined.

\section{Conclusions: Ecclesiastical drift and the future of Australian Catholic school religious education}

Ecclesiastical drift has resulted from efforts intended to rejuvenate the Catholic Church; it emphasised a church perspective on enhancing the religious life and practice of students, and this created ambiguity about the educational purposes of religious education. One can understand the legitimate hopes of bishops, clergy and Catholics generally that young people will engage with the church, and that a Catholic school education will favourably dispose them in this direction. But this hope is not a realistic or appropriate immediate purpose of religious education - it can educate them very well religiously, but this does not automatically generate personal faith and active church membership. Ecclesiastical drift tends to make the unrealistic presumption that what happens to pupils psychologically during religion lessons will change their faith and religious practice. A successful, relevant religious education cannot adequately be appraised in terms of traditional religiosity performance indicators like Sunday mass attendance. As long as the debate remains focused on religious education as a major factor in promoting church engagement, the real issues behind the decline in Catholic Church active membership will not be faced.

The problem derives primarily from thinking that Catholic schools and religious education can create church-going Catholics. Ironically, children are now becoming Catholics just to get into Catholic schools. Some non church-going parents are having their children (5-8 year olds) baptised and sacramentally 
initiated because in their context this is necessary to secure entry to a desirable Catholic school; in the long run, it does not change the families' level of religious practice.

Ecclesiastical drift has affected students and their parents' perceptions of religious education; it inclines them to see it an ecclesiastical activity, and not an educational one. It is like a nominal requirement of Catholic school authorities that they accept and go along with because they value Catholic schooling highly. But it is regarded as largely irrelevant to the personal development and education of the students. This reinforces their impression that religious education was not really an integral part of the curriculum.

The idea of 'forming' the faith of Catholics is an unrealistic and inappropriate purpose for religious education where most of the Catholic students are not church-going and about a third of all students are not Catholic. Educating the spirituality and faith of all students is what religious education is about.

It appears that ecclesiastical drift has contributed to the erosion of the perceived academic status of religious education in Catholic schools, which was at a higher level in the 1990s.It contributed to a decline in young people's perception of how meaningful and valuable religious education might be - with consequences for their level of engagement and readiness for an academically challenging study. In Years 11-12 in a large a number of Australian Catholic secondary schools, religious education takes on the format of government approved religion studies courses with university entrance academic credentials (E.g. Studies of Religion in NSW and Qld., and similar programs in other states). The persistence of these programs in Catholic schools may well help significantly in 'keeping an academic flag still flying' for religious education. By contrast, there is growing evidence that approved school and system developed religion courses (not contributing to university entrance) like Catholic Studies, have very low perceived academic status and are often considered by students to be a waste of time; but they may be preferred over religion studies because they make few if any academic demands on their time when they are under considerable pressure to perform well in the academic subjects that count toward future education and career options; if they have to do some religion, then the Catholic Studies option will provide the least interference in their secular studies. ${ }^{40}$

${ }^{40}$ Cf. G. Rossiter, Life to the full: The changing landscape of contemporary spirituality. Implications for Catholic school religious education, Sydney 2018: Agora for Spiritual, Moral and Religious Education, p. 131. 
As state funded, Australian 'semi-state' Catholic schools are accountable to the governments and the wider community for their responsibility to educate young Australians. They need to be able to explain their distinctive religious dimension in a way that is consistent with section 116 of the constitution which does not permit funding for activities that might constitute the 'establishment of a religion'. When this issue went before the Australian High Court (1978-1981, the Defence of Government Schools case), it was decided in favour of the Catholic church because there was sufficient evidence of an educational justification for educating young people religiously, especially with respect to their own tradition. It could be argued that such a religious education also contributed to the common good. If there is an extravagant emphasis on ecclesiastical processes and outcomes for religious education, this could in the long term be seen as contravening Section 116 and thus endangering the constitutionality of government funding for Catholic schools which has become essential for their economic survival and growth.

\subsection{Is ecclesiastical drift evident in Catholic Religious Education in other countries?}

Some international colleagues involved in Catholic Religious Education have indicated that the problem of ecclesiastical drift can be identified in their contexts - United Kingdom, Ireland, Europe, North America and New Zealand. They also noted that the influence is modulated by differences from the Australian context (E.g. whether schools are publically funded, whether or not there are government approved religion studies courses etc.). One European scholar said that "The longing for reconfessionalisation (even in the form of a hidden recontextualisation) is everywhere". Two scholars independently, in the UK and the USA suggested that the title 'ecclesiastical drift' was too soft. They recommended a more confrontative description "Intentional ecclesiastical restorationism".

The time is ripe for empirical research on this topic both in Australia and internationally.

\subsection{The future trajectory for Catholic school religious education in Australia} In the light of the issues discussed here, one might wonder what the future trajectory for Catholic religious education might be. Will it continue in the direction described as ecclesiastical drift, and for how much longer? Will Catholic 
authorities ever stop assuming that religious education - a part of compulsory education paid for mainly by the state - is, against all the evidence, primarily about changing the religious practice of students? Or is there any chance there could be a 'course correction' as proposed in the first part of the article? In my professional opinion, school religious education (but not the Catholic school system) is at a crossroads. The purpose of this writing is to advocate that the questions raised about long-term purposes and direction (with inevitable implications for content and pedagogy) need to be addressed with urgency. If not, I fear that ecclesiastical drift will further erode religious education, devaluing its perceived academic status and its important core position in the Catholic school curriculum, as well as diminishing its capacity to enhance the education and personal/spiritual development of students.

A type of 'geological fault line' has gradually developed between the normative discourse of Catholic religious education and the real situation in the classroom. If ecclesiastical drift is not going to further widen this fault line, the discourse needs to shift away from the current dominant, 'inward looking', ecclesiastical metaphors towards more 'outward looking' concerns about how to educate young people spiritually, morally and religiously. This needs to happen first to facilitate changes in content and pedagogy. As considered earlier, such an approach is just as important for religious, as well as relatively nonreligious, young people. It does not substitute for, or replace a good education in the Catholic religious tradition. But it can help religious education become more capable of helping young people make better sense of the very complicated spiritual/moral climate of these times, informing their decision making as they try to chart purposeful happy lives. ${ }^{41}$

Whether or not there might be a course correction ultimately depends on the Catholic religious education authorities. The diocesan religious education personnel across the country would need to be persuaded that such change is necessary; and they would then need to secure the approval of the bishops. Some Individual teachers and schools have already shown indications that the change agenda is being addressed; there will always remain some scope, even if limited, for flexibility and creativity in content and pedagogy. But the sort of grass roots, widespread changes in religious education that occurred in the 1960 and

${ }^{41}$ Cf. P. Hughes, Educating for Purposeful Living in a Post-Traditional Age, Melbourne 2017: Christian Research Association. 
$1970 s^{42}$ could not occur again within the now more centralised Catholic school systems. Given the recent history in which ecclesiastical constructs like Catholic identity, faith formation and evangelisation have strongly coloured (and even supplanted) understandings of religious education, it is difficult to hope that any signs of change would appear on the horizon any time soon. It is hard to change one's language when talking about religious education if the currently accepted normative key constructs/words are deeply embedded. When they become 'buzz' words or clichés, they tend to have presumed, but vague, universal meaning that inhibits educators from carefully thinking through how best to articulate the purposes of religious education in non-jargon terms. ${ }^{43} \mathrm{Also}$, for some there is the problem explicated by Festinger's Cognitive Dissonance Theory, ${ }^{44}$ where they do not pay attention to the evidence that contradicts or raises questions about the way they construe things to be. Ecclesiastical drift seems to have become such a well-established and unquestioned norm in the thinking of Catholic religious education authorities that it has become a prejudiced position. Einstein is reported to have said that it was easier to split the atom than to break down prejudice.

If ecclesiastical drift continues, one might expect that the place of religious education in the senior school will be further diminished. Some schools are already thinking about how it might be discontinued, or minimalised with an alternative that shows that some sort of 'religious flag' is still flying.

If such a negative prognosis eventuates, perhaps the greatest disappointment that religion teachers will feel is that religious education is being stifled just when the need for a relevant religious education is much greater and more important than at any former time. Young people today live in a culture where the expectation is that they construct their own meaning, values and beliefs in an individualistic fashion. This is not going to change. But their education could help them address the many puzzling and threatening questions that they are constantly facing as they make their way through the maze of contemporary culture. Religious education could be adapted to be the one subject area in the

${ }^{42}$ Especially in the communitarian retreat movement. Cf. G. Rossiter, Research on retreats: A study of the views of teachers and students about retreats in Australian Catholic secondary schools, Sydney 2016: Australian Catholic University School of Education NSW.

${ }^{43}$ Cf. G. Rossiter, Life to the full: The changing landscape of contemporary spirituality. Implications for Catholic school religious education, Sydney 2018: Agora for Spiritual, Moral and Religious Education, p. 132.

${ }^{44}$ Cf. L. Festinger, A theory of cognitive dissonance, Stanford 1962: Stanford University Press. 
curriculum that takes up this agenda formally and realistically. Hill's comments (quoted earlier) saw this role as "Resourcing the choosing self. ...helping them to interrogate their own cultural conditioning". This is potentially one of the most important needs in contemporary education in any sort of school, public and private - at a time when employment-oriented and economic agendas, allied with excessive 'quality control industry' practices, are dominating Australian education.

In my teaching experience, postgraduate students strongly affirmed this evaluative role for religious education. It was tested successfully in that arena, but as yet has not been tried widely or systematically in schools, even though individual teachers have long included critical evaluative elements in their pedagogy. Religion teachers have told me that they considered a great educational opportunity for religious education was being missed as long as the discourse was locked into trying to 'imbue Catholic identity'. For their students, they judged that this focus was perceived to demonstrate a 'Catholic ghetto' mentality. While not angry about this, students tended to quietly ignore the 'Catholic bit' as a nominal, but irrelevant part of the education that they valued overall. As far as any study of beliefs, values and lifestyle was concerned, most students tended to shun any inward-looking institutional approach; they were naturally attuned to a more outward-looking, democratic, and expansive view of life.

There appears to be some anomaly in the current situation because, while there have never been more theologically well qualified religion teachers in the history of Australian Catholic religious education, the status of the subject is low and there is considerable student and parent disinterest. I believe that ecclesiastical drift leaves religion teachers somewhat hamstrung because they are caught up in a web of unrealistic, inappropriate expectations, without the opportunity to change purposes, content and method in ways that may improve the meaningfulness and relevance of the subject, as well as its academic status. But there is initial action they can take by not using the problematic ecclesiastical terms and by talking about religious education in ways that make more sense to teachers, students and parents.

The sort of leadership that one might hope for from religious education authorities was demonstrated recently by Archbishop Kohlgraf of Mainz in Germany. ${ }^{45} \mathrm{He}$ identified the problematic way the term evangelisation had become

${ }^{45}$ Cf. P. Kohlgraf, La Croix Report on Archbishop Kohlgraf's comments, 2019. https:// international.la-croix.com/news/german-bishop-opposes-evangelization-as-a-battle-cryagainst-reform/11018\# (11.11.2019). 
a "battle cry" or slogan when used ubiquitously without relevance to the wider world. He felt that such usage tended to cripple the discourse about a contemporary, meaningful faith because it created a gulf between the church's narrative and the reality of people's daily lives. His use of the term battle cry is significant and pertinent to the ecclesiastical drift problem in religious education - one teacher recently told me he considered that the "church language for RE has now become weaponised". The archbishop was also concerned that when ecclesiastical terms became clichés, the real issues to be faced tended to be 'trivialised' - similarly for religious education. Another local teacher's comment: “The RE terminology sounds like a repetitive TV advertisement trying to sell something that you are not interested in".

Religion has long served as the standout, lone, spiritual/moral subject in Australian school education (ethics and philosophy have had a very small presence, with contributions from personal development education);it can deal with spiritual and moral issues as its direct content. Because of the current centrality of religious education in their curriculum, Australian Catholic school systems have by far the great bulk of the country's religion teaching resources. It may seem fanciful to say this, as the prospect is unlikely in the present circumstances, but these schools have the potential to be a lighthouse for Australian education in showing how a spiritual/moral dimension is fundamentally important for the curriculum in all schools. And they could model the way this could be addressed in different subject areas. Catholic religious education, suitably adapted to address contemporary spiritual/moral issues (along with its commitment to teach about Catholicism), could show a way forward. But to do this, it would need to be more broadly focused on educationally resourcing the spirituality of young people and not so exclusively on Catholic identity and faith formation (An example of how a start might be made in this direction is given in Appendix 1). As long as ecclesiastical drift dominates the discourse of Catholic religious education, it will have little that is meaningful to say to the rest of the country let alone to its own students - about how best to educate young Australians spiritually, morally and religiously.

I predict that eventually history will acknowledge how the dominance of ecclesiastical drift has talked the discourse of Australian Catholic religious education into an 'ideological cul-de-sac', diverting it from a less ecclesio-centric path to greater meaningfulness and relevance for $21^{\text {st }}$ century young people. History has shown how the curricular freedom of Catholic religion teachers and schools in the 1970s and 1980s resulted in both helpful 
and non-helpful experiments and developments; but what has never been in question was their absolute commitment to trying to make religious education relevant for their pupils. This study appeals to that same commitment in contemporary religion teachers and authorities; hopefully it might prompt further consideration of the arguments and issues presented here - a catalyst for action. Ecclesiastical drift has created ambiguity about the purposes, practices and content of Catholic religious education - especially at the senior school level. It is time to put religious education 'back on the Catholic school map' - front and centre.

\section{Some signs:}

(i) In 2018, the Australian National Catholic Education Commission published Framing paper: Religious Education in Australian Catholic Schools as a leadership document. It stressed the educational dimension to religious education and did not overemphasise ecclesiastical constructs - Catholic identity was referred to only once while the words religious education were used 86 times and religion 14. Religious education was said to be distinct from, but complementary to, faith formation; the problematic connotation of faith formation was not considered. Its discussion of the desired characteristics of religious education appears capable of readily accommodating the critical evaluative approach proposed at the beginning of this article. ${ }^{46}$

(ii) Beginning in 2018, the Brisbane Catholic Education Office started developing a new Year 11-12 course option named Religion, Meaning and Life (this course would not have university entrance academic status like Studies of Religion). Its opening paragraph reflected an outwards looking, critical evaluative approach. But the 4 units of content remained traditional - on God, Scripture, Jesus and the Catholic Church. "Young people are confronted by the complexities, dilemmas and conflicting interpretations of life's meaning and purpose. They require, more than ever, the skill of critical thinking in order to navigate an uncertain and pluralistic world. As there is no final answer to life's ultimate meaning and purpose in which intellectual certainty is possible, human knowledge is always partial and limited. Consequently, students are invited to explore within Religion, Meaning and Life (RML) the inexhaustible mystery of human

${ }^{46}$ Cf. G. Rossiter, Life to the full: The changing landscape of contemporary spirituality. Implications for Catholic school religious education, Sydney 2018: Agora for Spiritual, Moral and Religious Education, pp. 92-93. 
existence, as glimpsed primarily through the lens of the Catholic Christian Tradition, as well as other religious traditions and help render this mystery meaningful in their lives."

(iii) Also in 2018, Catholic Education Offices in NSW developed a similar course option called Studies in Catholic Thought, where the word Catholic was used more than 500 times in the draft syllabus. The opening paragraphs in the rationale were. “...Studies in Catholic Thought develops students' understanding of the Catholic tradition. It offers students the opportunity to focus on one religion that has made a significant contribution to the world; spiritually, ethically, politically, and socially. Studies in Catholic Thought requires students to engage with the theological, philosophical, ethical and aesthetic tradition of the Catholic Church. It equips students to engage with the richness of this faith tradition and the complex ways it continues to captivate people and ideas throughout the ages and in the modern world. Studies in Catholic Thought draws upon the liberal arts approach, to develop and challenge students' thinking and analytical skills as they engage with the depth and breadth of the Catholic tradition."

Studies in Catholic Thought will assist students to make sense of everyday life in the broader context of mystery, complexity, confusion and awe. 


\section{Appendix 1.}

\section{An example of how to avoid ecclesiastical drift by changing the discourse of Catholic school religious education-by de-emphasising ecclesiastical language and adding more educational descriptions of purposes}

\section{ECCLESIASTICAL DRIFT LANGUAGE EXAMPLES}

Problematic when used as the only and exclusive way of articulating the purposes of religious education.

The Catholic school is founded on the person of Jesus Christ

The Catholic school within the community of believers integrates faith with life, and faith with culture.

The Catholic school shares in the evangelising mission of the Catholic church.

Catholic schools exist so that there can be places where the whole effort of education is conducted in, permeated by, shot through with that understanding of the world which places God at the heart of everything

(Bishop's statement for the Episcopal Committee for Education, 2017)

The Catholic school is a centre of New Evangelisation

The Catholic school helps children to love and serve Jesus

\section{ADDING COMPLEMENTARY, COMPENSATING EDUCATIONAL STATEMENTS}

Adding statements that are more educational, less Catholic-centric and more concerned with pupils' personal development in times where the cultural context is complex and troublesome

The partnership between the Church, Government and Parents enables Catholic schools to make a significant contribution to the education of young Australians

Catholic schools have always given special attention to the spiritual, moral and religious dimensions of education and provide leadership in this domain for Australian school education

Catholic schools educate young people spiritually, morally and religiously for life in the $21^{\text {st }}$ century.

Catholic school religious education helps young people learn how to negotiate a meaningful life through the challenging maze of contemporary culture.

Religious education is a curriculum area where young people can learn how to evaluate critically the shaping influence of culture

Religious education gives young people access to their religious heritage and it resources their spirituality with skills for their search for meaning and values in life. 


\section{Bibliography}

Birch L.C., Personal communication, 1967.

Birch L.C., Confronting the future: Australia and the world: The next 100 years, Melbourne 1975: Penguin.

Boeve L., Interrupting Tradition: An Essay on Christian Faith in a Postmodern Context, Louvain 2003: Louvain Theological and Pastoral Monographs.

Boeve L., Religion after detraditionalization: Christian faith in a post-secular Europe, "Irish Theological Quarterly" (2005) 70 (2), pp. 99-122.

Boeve L., God interrupts history: Theology in a time of upheaval, New York 2007: Continuum.

Boeve L., Communicating faith in contemporary Europe: Dealing with language problems in and outside the church, in: J. Sullivan (Ed.), Communicating faith, Washington 2011: Catholic University of America Press.

Boeve L., Theology at the Crossroads of University, Church and Society: Dialogue, Difference and Catholic Identity, London 2016: Bloomsbury.

Brisbane Catholic Education Office, Religion Meaning and Life Course Description (Draft). Brisbane 2019: Brisbane Catholic Education Office.

Buchanan M.T., The Transmission of Religion: Reconceptualising the Religious Education Leader, in: M.T. Buchanan \& A.-M. Gellel, (Eds.),Global Perspectives on Catholic Religious Education in Schools: Volume II: learning and leading in a pluralist world, Singapore 2019: Springer Nature.

Catholic Bishops of NSW \& ACT, Catholic schools at a crossroads: Pastoral letter of the bishops of NSW and the ACT, Sydney 2007: Catholic Education Office.

Catholic Episcopal Conference (Australia), The Renewal of the Education of Faith, Sydney 1970: EJ Dwyer.

Congregation for Catholic Education, The Religious Dimension of Education in a Catholic School, 1988, Vatican Website.

Crawford M. \& Rossiter G., Missionaries to a teenage culture: Religious education in a time of rapid change, Sydney 1988: Christian Brothers Province Resource Group.

Crawford M. \& Rossiter G., Reasons for living: Education and young people's search for meaning, identity and spirituality. A Handbook, Melbourne 2006: Australian Council for Educational Research.

Festinger L., A theory of cognitive dissonance, Stanford 1962: Stanford University Press.

Fowler J., Stages offaith: The psychology of human development and the quest for meaning, Melbourne 1981: Dove Communications.

Frankl V., Man's search for meaning, London 1964: Hodder \& Stoughton.

Gorman G., Troll hunting: Inside the world of online hate and its human fallout, Melbourne 2019: Hardie Grant.

Grimmitt M.H., Religious education and human development: The Relationship between studying religions and personal social and moral education, Great Wakering 1987: McCrimmons. 
Hesburgh T., The challenge and promise of a Catholic university, South Bend 1994: University of Notre Dame Press.

Hill B. V., Exploring religion in school: A national priority, Adelaide 2004: Openbook.

Hill B.V., Values in free fall: Religious education and values in public schools, "Journal of Religious Education" (2006) 54 (2), pp. 51-58.

Hill B.V., Personal communication, 2020.

Hughes P., Putting Life Together, Melbourne 2007: CRA / Fairfield Press.

Hughes P., Educating for Purposeful Living in a Post-Traditional Age, Melbourne 2017: Christian Research Association.

Jackson R., Rethinking religious education and plurality: Issues in diversity and pedagogy, London 2004: Routledge Falmer.

Jackson R., Religious Education for Plural Societies, London 2018: Routledge.

Kohlgraf P., La Croix Report on Archbishop Kohlgraf's comments, 2019. https://international.la-croix.com/news/german-bishop-opposes-evangelization-as-a-battle-cryagainst-reform/11018\# (11.11.2019).

Lovat T., What is this thing called Religious Education? (3rd Edition), Terrigal 2009: David Barlow.

McBrien R.P., Catholicism. Melbourne 1976: Dove Communications.

Morey M. M. \& Piderit J.J., Catholic higher education: A culture in crisis, New York 2006: Oxford University Press.

NCEC, NCEC 2012 Annual Report. Canberra 2012: National Catholic Education Commission (NCEC).

NCEC, A Framework for Formation for Mission in Catholic Education, Sydney 2017: National Catholic Education Commission (NCEC).

NCEC, Framing Paper: Religious Education in Australian Catholic Schools, Sydney 2018: National Catholic Education Commission (NCEC).

NSW Catholic Education Offices, Syllabus document for Studies in Catholic Thought (Draft), Sydney 2018: NSW Catholic Education Offices.

O’Donoghue T.A. \& Byrne D., Historical Inquiry into the Construction of Religion as a School Subject for Catholic Schools in Australia, "eJournal of Catholic Education in Australasia" (2014), Vol. 1: Iss. 1, Article 2. Available at: http://researchonline. nd.edu.au/ecea/vol1/iss1/2.

Pajer F., School-based education and religious culture: A European approach to the problem of teaching religion in school. De La Salle Brothers International (2003) MEL Bulletin 6. Published in the "Journal of Religious Education" (2006) 54 (4), pp. 37-45.

Phenix P., Realms of meaning: A philosophy of the curriculum for general education, New York 1964: McGraw Hill.

Pollefeyt D. \& Bouwens J., Framing the identity of Catholic schools: Empirical methodology for quantitative research on the Catholic identity of an education institute, "International Studies in Catholic Education" (2010) 2 (2), pp. 193-211. 
Pollefeyt D. \& Bouwens J., Identity in Dialogue: Assessing and enhancing Catholic school identity. Research methodology and research results in Catholic schools in Victoria, Australia, Melbourne 2012: Catholic Education Commission of Victoria and Katholieke Universiteit Leuven (Faculty of Theology and Religious Studies, Final Draft for Publication). Melbourne: Catholic Education Commission of Victoria and Katholieke Universiteit Leuven. Published in 2014 by Lit Verlag GambH \& Co, Zurich.

Pope Francis I, The interview with Pope Francis I, "La Civiltà Cattolica", August 2013 (English translation, "America”, September 30, 2013).

Postman N. \& Weingartner C., Teaching as a subversive activity, Harmondsworth 1969: Penguin.

Rossiter G., The Place of Knowledge in Religious Education: The Debate over Doctrine in Religious Education, "Our Apostolate" (1977) 25 (4), pp. 214-223.

Rossiter G., Religious Education in Australian Schools, Canberra 1981: Curriculum Development Centre.

Rossiter G., The 'Catholicity' of Catholic schools and the development of students' religious identity, "Word in Life" (1997), 45 (2), p. 20.

Rossiter G., The problem of the erosion of religious identity: Implications for religious education, "Word in Life" (1997), 45 (4), pp. 30-31.

Rossiter G., Historical perspective on the development of Catholic Religious Education in Australia: Some implications for the future, "Journal of Religious Education" (1999), 47(1), pp. 5-18.

Rossiter G., Research on retreats: A study of the views of teachers and students about retreats in Australian Catholic secondary schools, Sydney 2016: Australian Catholic University School of Education NSW.

Rossiter G., Life to the full: The changing landscape of contemporary spirituality. Implications for Catholic school religious education, Sydney 2018: Agora for Spiritual, Moral and Religious Education.

Ryan M., A common search: The history and forms of religious education in Catholic schools (Revised Edition), Brisbane 2013: Lumino Press.

Schweitzer F., Religious individualization: New challenges to education for tolerance, "British Journal of Religious Education" (2007) 29 (1), pp. 89-100.

Second Vatican Council, Gravissimum Educationis,1966, Vatican Website.

Sharkey P., Educator's Guide to Catholic Identity, Melbourne 2015: Vaughan Publishing.

Sharkey P., Better understanding of the context of religious education: The CEVC Leuven Research, in: R. Rymarz and A. Belmonte (Eds.), Religious Education in Australian Catholic Schools: Exploring the landscape, Melbourne 2017: Vaughan Publishing.

Sterkens C., Hermans C.A.M., Van der Ven J.A., Formation of the Religious Polyphonic Self: Interreligious Learning in Religiously Affiliated Schools, in: P. Ploeger \& C. Sterkens (Eds.), Search for Meaning. Education into Realms of Meaning in a Plural Society, Kampen 1999: Kok, pp. 219-250.

Strommen M., Five cries of youth, San Francisco 1974: Harper \& Row. 
Swinton J. \& Mowat H., Practical theology and qualitative research, London 2016: SCM. Westerhoff J.H., Will our Children have Faith?, Melbourne 1976: Dove Communications. Zakaria F.,GPS. Global Public Square. Program for discussion of contemporary social and political issues on CNN, 2019. See https://www.cnn.com/shows/fareed-zakaria-gps https://globalpublicsquare.blogs.cnn.com/category/gps-episodes/ https://globalpublicsquare.blogs.cnn.com/ 